\title{
Validation of the Team Factors Inventory in Brazilian Companies
}

\author{
Fernando Antonio Prado Gimenez* \\ E-mail address: gimenez@unicenp.edu.br \\ Centro Universitário Positivo - UNICENP \\ Curitiba, Pr, Brazil \\ Edmundo Inácio Júnior \\ E-mail address: eijunior@ige.unicamp.br \\ Universidade Estadual de Campinas \\ Pirassununga, SP, Brazil
}

\begin{abstract}
The aim of this paper is to test the validity and reliability of a Portuguese version of the Team Factors Inventory/TFI derived from the Creative Leadership Model. This inventory measures the propensity of a team towards creative leadership and consists of a paper and pen measure with 37 items on a Likert-type scale. The literature concerning creativity in organizational studies has focused mainly on the contribution the individual makes to innovation and technical change. The model of Creative Leadership, on the other hand, has turned attention to group behaviour and team management. The model has been recently proposed in England and there are no literature reports on its application in a language other than English. The method involved a review of the literature on creative leadership, backtranslation of the inventory, and data analysis through descriptive statistics, hypotheses testing, factor analysis, and analysis of variance, using as control variables, sex, and type of enterprise. The sample consisted of 115 respondents, with 73 owner-managers of high-tech incubated firms and 42 owner-managers of service firms. Analyses indicated that the translated version Portuguese of the inventory reached satisfactory levels of validity and reliability. This means that the TFI may be applied in a cultural context other than the original.
\end{abstract}

Key words: creative leadership; entrepreneurship; creative team factors; reliability; validity.

Received 05 November 2004; received in revised form 10 February 2005.

Copyright (C) 2006 Brazilian Administration Review. All rights reserved, including rights for translation. Parts of this work may be quoted without prior knowledge on the condition that the source is identified.

* Corresponding author: Fernando Antonio Prado Gimenez

Av. João Gualberto, 381/902, Centro Cívico, 80030-000, Curitiba, PR, Brazil. 


\section{INITIAL CONSIDERATIONS}

One of the concerns in carrying out research is to avoid as much as possible those errors that may lead to data misinterpretations (Craig \& Douglas, 2000). From the sources of errors pointed out by the authors, four of them comprise all the likely universe of errors: the respondent, the situation, the evaluator and the instrument (Cooper \& Schindler, 2002). This article is meant to verify the reliability and validity of the Portuguese version of the instrument Team Factors Inventory - TFI (fourth source of error). The first three sources of errors are not addressed in this article as they have already been under investigation in other papers (Inácio Jr., 2002; Inácio Jr., Gimenez, \& Caetano, 2002).

There are, according to the authors, three main evaluation criteria for the evaluation of a measurement instrument: validity, reliability and practicality (Cooper \& Schindler, 2002). Validity refers to the extent a test may measure what it is meant to measure whereas reliability concerns issues of stability and consistency. Both have to do with accuracy and precision of a measurement instrument. Practicality relates to several factors of economy, convenience and interpretability (Singleton Jr et al., 1993). These three criteria will be considered in order to support our analyses and conclusions in regard to the adequacy of the TFI to measure the potential of Creative Leadership in entrepreneurial and innovative teams.

These themes - creativity and entrepreneurship - have overlapping areas as the act of enterprising a business has been seen as a complex and multifaceted process, being influenced by social variables (social mobility, culture, society), economic variables (market incentives, public policies, risk capital) and psychological variables (Carland \& Carland, 1991; Huefner et al., 1996; Kets de Vries, 1985). Of the characteristics of the entrepreneur the most cited are: internal locus of control, need for achievement, risk propensity, creativity, vision, high energy, strategic posture and self-reliance (Brockhaus, 1982; Hornaday, 1982; Carland, Hoy, Boulton \& Carland, 1984; Vesper \& Gartner, 1997).

In this article the most adequate definitions for the study of the entrepreneurship phenomenon come from the works by Filion (1999a, 1999b) and Stewart Jr. et al. (1999). These authors agree that entrepreneurship is the tangible or intangible result of an individual with creative skills, being a complex function of life experiences, opportunities and individual capacities that presents both in his life or career the risk variable. In other words, the entrepreneur is someone who, in the process of constructing a vision, establishes a business to obtain profit and growth with an innovative behavior and the adoption of a strategic posture (Bruyat \& Julien, 2001).

The literature on creativity in organizational studies has focused mainly on the contribution the individual makes to innovation and technical change (Amabile, 1998). The model of Creative Leadership, on the other hand, contributes towards filling this gap, turning its attention to the group behavior and team management. The model has recently been developed in England and there are no literature reports on its application in a language other than English. This present research corroborates this context by enabling the investigation of a trend in the entrepreneur's behavior: Creative Leadership

The TFI measures the potential for Creative Leadership in innovative and entrepreneurial teams and consists of recent efforts for the construction of a new model to explore the processes that contribute for a team high performance in innovative activities (Rickards \& Moger, 1999, 2000). Despite the existence of empirical works and statistical analyses in the original English version (Rickards et al., 2001), this is the first time the instrument has been applied in Brazil. Therefore, the analysis of its validity and reliability is required, for "[...] the researcher that assumes that a scale developed for a local use will serve the same purposes and with the same efficacy somewhere else is most likely looking for trouble" (Knight, 1997, p. 213).

Our intention is to verify whether the TFI is capable of discriminating between the answers from groups of entrepreneurs who have different business characteristics, i.e., whether owner-managers of 
high-tech incubated micro and small-sized firms from the State of Paraná have more Creative Leadership than those from a more technologically mature environment with fewer opportunities and working in traditional sectors of services in the city of Maringá.

In this work we have called owner-managers those individuals involved with the routine management of a company (Filion, 1999a, 1999b). Any person may take the role of an entrepreneur even if he never becomes the owner-manager of a micro or small-sized firm, as may be the case of those who work for others. On the other hand, owner-managers of micro or small-sized firms may not be considered entrepreneurs as, in general, they administer daily routines and do not affect significantly the products or services.

Furthermore, whenever we refer to high-tech incubators we mean those enterprises that provide physical space, for a limited period of time, for the installation of technological firms with a technical team for support and consulting services. These firms are called residents, i.e., they are under the process of incubation and make use of the infrastructure and the services offered by the incubator in its physical area and for a limited time.

Our presupposition is based on the idea that this type of business (technology-based) may be an appropriate environment for the emergence of innovative behaviors in teams, and, as proposed in recent studies, for the manifestation of Creative Leadership (Brush, Greene, \& Hart, 2002; Rickards, 1999).

Thus, a sample of 115 respondents was taken from these two groups, 73 from technology-based companies and 42 from firms of delivery of services. This article has five other sections besides its Initial considerations and the Bibliographic References. The second section The model of Creative Leadership explains the main antecessors and precepts proposed by its authors (Rickards \& Moger, 2000). Section three, The Instrument, describes the TFI. The methodological procedures are presented in section four The Sample. Section five, Results, is devoted to the analyses of validity and reliability. Finally, the sixth section Final Considerations highlights the main results from the adequacy of the TFI and Creative Leadership into the Brazilian context and provides some suggestions for further works.

\section{THE CREATIVE LEADERSHIP MODEL}

One of the recent theories on the processes of group creativity is the model of Creative Leadership (Rickards \& Moger, 2000). For the authors, Creative Leadership is the fundamental process that changes a team's creative behavior from unacceptable to acceptable and later superior performance, through the introduction of benign structures, with an emphasis on cooperation (not coercion) and mutuality (situations that provide benefit to the group and to the leader at the same time). There are also other authors who have highlighted the role of the leader in the groups and his importance in creative processes. Among them are the ideas about collaborative team work and the significant leader role in this context (Bennis \& Biederman, 1997) and the model of Connective Leadership (LipmanBlumen, 2000) that relates to the activity of the entrepreneur and the strategies of leadership and creativity frequently adopted by him.

The attention Rickards and Moger give to the benign structures, associated with the creative team process, is in harmony and accordance with other works that show the importance of a shared base of understanding, principles and knowledge (Alencar, 1995; Nonaka \& Takeuchi, 1997; Alencar, 1998). Benign structures must expand individual and group activities, under the diverse group contingencies (Rickards \& Moger, 2000). However, Rickards and Moger believe that there are barriers that block the insertion or development of those benign structures - that emphasize cooperation and mutuality - in the group and, thus, prevent the teams from performing in expected creative ways. 
These authors used the model of team development (Tuckman, 1965) to explain how the factors of creative teams may influence their process of formation. This model addresses the phases that make up the process of a team formation: a) form, b) storm, c) norm, d) perform. A fifth phase was added later, e) adjourn.

The form phase consists of a phase of guidance and organization of roles among the members of the working team and proceeds until the interpersonal conflicts have been exposed and identified. During the storm phase there is a constant conflict of values and objectives among the members. The conclusion of this phase is evidenced by the establishment of a norm of behavior and relationship of the members; the efforts of the team may then be totally devoted to their common tasks and objectives - the perform phase. The last phase, adjourn, is identified during the end of the team work. At this moment, the results obtained by the team are evaluated by the organization and the conclusions may lead to the extinction of the team or, very often, a likely adequacy of the team to new objectives, or the continuation of the team work (Rickards \& Moger, 2000).

Rickards and Moger (2000) modified this model with the inclusion of two barriers - a weak barrier of behavior and a strong one of performance - that are inherent to the process of formation and performance of the teams, which, at first, prevent them from being formed, and later, from achieving superior results. According to the authors, this was needed because the model itself was not enough to answer two questions "what mechanisms are at stake when a team fails to achieve an expected performance? And which mechanisms lead to exemplary performance?" (Rickards \& Moger, 2000, p. 275). Figure 1 illustrates the model.

Figure 1: Tuckman's Revised Model of Team Formation

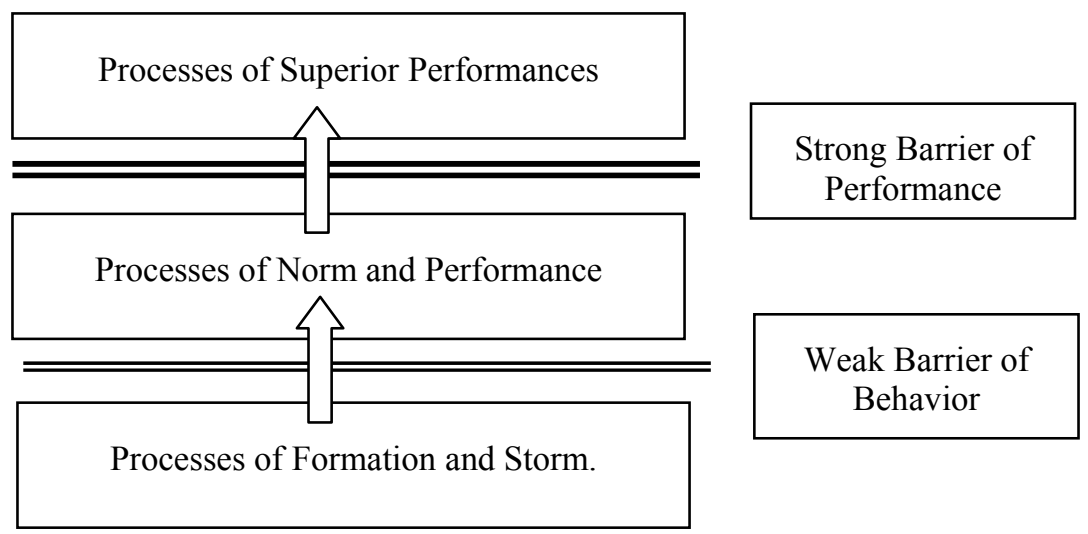

Source: Rickards et al. (2000).

The first barrier is considered a weak barrier of behavior and is found in groups unable to surpass the phase of form and storm. To surpass this barrier means that the members of the group were able to establish personal relationships among themselves and with the leader, and it is considered weak by Rickards and Moger (2000), as they have observed that most creative teams can overcome it. The second, considered a strong barrier of performance, indicates the capacity of creativity and innovation achieved by the group. The evaluation of this creative performance is dependent on the organizational culture, as noted by the authors.

In order to overcome these two barriers, and others, that are contingent in groups, Rickards and Moger (2000) reinforce the insertion of the benign structures that are represented by the seven factors of creative teams distinguished by their high creativity potential: platform of understanding; shared vision; climate; resilience; own ideas; network activation; and learning from experience. The greater or lesser presence of these factors of creative teams may break the two existing barriers that prevent the insertion or development of benign structure in the group and which, consequently, make the teams unable to achieve the expected creative performance. Rickards and Moger (2000) employ the term barrier to indicate a structural impediment to the development of creativity. The authors see 
these barriers to the development of a team both externally, like environment pressures, and internally, as socially built barriers.

\section{THE INSTRUMENT}

The long-term experience of the authors with the study of the problem-solving model and with the studies of creativity in groups was the starting point for the development of the TFI (Rickards, 1999; Rickards \& Moger, 1999). At first, for each factor, a definition was given in the form of an affirmative statement. Next, three or four affirmative sentences were made for each definition. The set of affirmative statements was presented to and discussed by graduate students from different origins and experiences and that led to the rejection or refinement of a small number of those sentences. The authors decided to select three of those statements for each of the seven factors as they believed these translated the core aspects of the definitions. Table 1 presents a brief description of the seven factors of creative teams, the code adopted for the analysis and the location of the affirmative statements in the TFI.

Furthermore, the authors included another four variables, with three items each. These variables accounted for three result criteria: productivity, creativity and knowledge, and one criterion of leadership style (Transactional and Transformational). The model of transactional versus transformational leadership was created by James MacGregor Burns, who is considered one of the most important contributors in leadership theories since the 1980 (Rickards, 1999, p. 123). Burns noted a fundamental difference of behavior in leaders that operated in a model close to that economic model of changes, which he called Transactional Leadership, and in leaders that kept a behavior beyond egotism, which he called Transformational Leadership. The Transactional Leadership relates to that leader who attempts to identify potential motivations in his followers, trying to meet the most elevated needs and to engage the whole self of his followers (Burns, 1979). On the other hand, the Transformational Leadership "results in a mutual relationship of stimulation and elevation, which converts followers into leaders and may convert leaders into moral agents." (Burns, 1979, p. 4). As the most common type of leadership, it relates to the leader who approaches his followers with the intention of exchanging something for something else, such as a job placement for a vote, or subsidies for campaign contributions (Burns, 1979, p. 4).

Therefore, the final TFI - see Annex 1 of the Portuguese version used in the research - comprised 36 items, even though it contained 37 affirmative statements. The first affirmative statement is dummy and was introduced to focus the attention of the respondent. The reason for the inclusion of these criteria of leadership style and result was to evaluate the impact of the seven factors of creative teams on themselves. The intention was to develop an instrument that could be used by team members and researchers. The design of the TFI was based on the premise of an attempt to establish a good balance between the highest possible level of reliability from the long questionnaires and the highest possible degree of acceptance from the respondents of the least long questionnaires. An important requisite was that most respondents should answer the instrument in no longer than five minutes. 
Table 1: The Criteria in the TFI

\begin{tabular}{|c|c|}
\hline $\begin{array}{c}\text { Criteria } \\
\text { (Code - No affirmat }\end{array}$ & Main characteristics \\
\hline \multicolumn{2}{|c|}{ Seven factors of creative teams } \\
\hline $\begin{array}{l}\text { Platform of } \\
\text { understanding } \\
\text { (PE - 19, } 27 \text { e 35). }\end{array}$ & $\begin{array}{l}\text { Team members understand and respect others points of view, the team } \\
\text { shares knowledge, beliefs and convictions. These elements include the } \\
\text { platform of understanding from which new ideas will be developed. }\end{array}$ \\
\hline $\begin{array}{l}\text { Shared vision } \\
(\mathrm{VC}-6,7 \text { e } 13)\end{array}$ & $\begin{array}{l}\text { Team members share sense of purpose and responsibility that motivate and } \\
\text { support the team progress. Team members also have powerful and } \\
\text { meaningful visions in common. }\end{array}$ \\
\hline $\begin{array}{l}\text { Climate } \\
(\mathrm{CL}-26,32 \text { e } 36)\end{array}$ & $\begin{array}{l}\text { Team members trust one another and share a positive and warming approach } \\
\text { to stimulate creativity at work. }\end{array}$ \\
\hline $\begin{array}{l}\text { Own ideas } \\
\text { (IP }-2,4 \text { e 9) }\end{array}$ & $\begin{array}{l}\text { The ideas receiving most attention are those perceived as open to the whole } \\
\text { team's commitment. A creative team develops and supports new and } \\
\text { valuable ideas of problems related to the work. }\end{array}$ \\
\hline $\begin{array}{l}\text { Resilience } \\
\text { (RE - 16, } 20 \text { e 34) }\end{array}$ & Team members are flexible in face of frustrations and obstacles. \\
\hline $\begin{array}{l}\text { Network } \\
\text { activation } \\
(\mathrm{AR}-17,21 \text { e } 23)\end{array}$ & $\begin{array}{l}\text { Team members are good at communicating with others from outside, } \\
\text { exchanging ideas and offering mutual support }\end{array}$ \\
\hline $\begin{array}{l}\text { Learning from } \\
\text { experience } \\
(\mathrm{AE}-14,15 \text { e } 33)\end{array}$ & $\begin{array}{l}\text { Team members are guided toward learning from their own experiences thus } \\
\text { allowing to grow, change, adapt and solve problems in a creative way. }\end{array}$ \\
\hline
\end{tabular}

Source: adapted from Rickards et al. (2001, p. 245).

A five-point scale - Likert scale - was chosen to measure all the TFI items as follows: $5=$ strongly agree; 4=agree; $3=$ =neutral; 2=disagree; $1=$ strongly disagree. All the statements were made in an affirmative way. The sentence style encourages the respondent to report on the general characteristics the team has experienced. The greater or lesser presence of the seven factors of the creative teams places the team, according to the TFI scale, between values 0 to 5 points, in three scopes: Team from hell $[0$ a 1,87$)$, Standard team $[1,87$ a 3,10$)$ e Dream team $[3,10$ a 5,00$]$.

As this is the first time these instruments have been used in Brazil, a translation from English to Portuguese was needed. For that, the backtranslation method was adopted (Craig \& Douglas, 2000), consisting of a translation of the original instrument - source - into the target idiom - target, and its backtranslation to the original idiom, again. Afterwards, the results are compared and, if necessary, the same process redone until the resulting instrument has the same meaning in its whole context. Normally, it is recommended that the translation should be done by a person whose mother tongue is the target idiom and that the backtranslation be made by a person whose mother tongue is the same as that of the original instrument.

\section{THE SAMPLE}

The sample of respondents was characterized by convenience, sufficiently large to avoid doubts as to its representation, both for the owner-managers of technology-based companies in the State of Paraná and for the owner-managers of traditional firms of services in the city of Maringá-PR. This assertion comes from the presuppositions found in the Theorem of Central Limit (Steverson, 1986; Silver, 2000) that ensures that the average sample represents the populational average of a large population, and a sample $n \geq 30$ would be statistically significant with a $95 \%$ level of reliability. 
Nevertheless, the authors took care in the selection of the sample size. First of all, the fact the population of technology-based companies may be considered small in size in relation to the hundreds of micro and small-sized firms of services was taken into account. Therefore, in order to assure the rigor of the analyses not only in this present research - the validity and reliability of the instrument but also the use of the data for the analysis of the results from the TFI itself, the determination of a probabilistic sample was taken from the formula for a finite population (small) with an estimation of rate as follows:

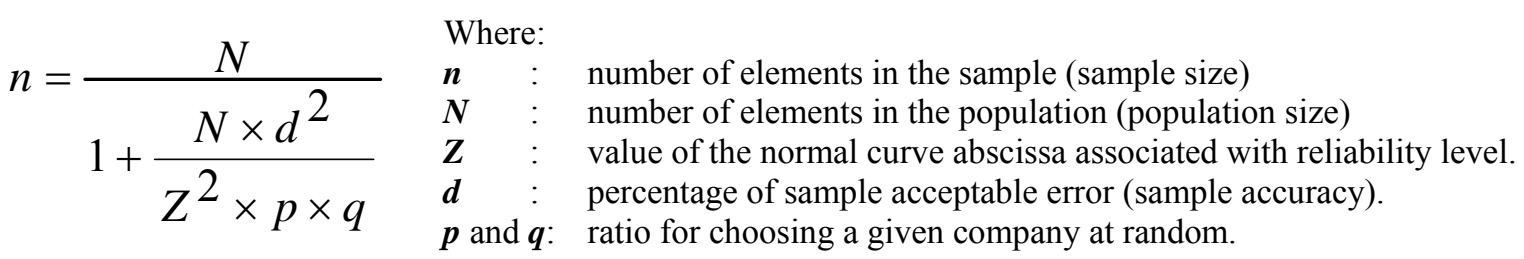

Source: Silver, 2000, p. 227.

Thus, with a population size $N=55$ of high-tech companies (data from 2000), for a pre-established significance level of $5 \%$, since for studies in social areas it is common to use this significance level (Steverson, 1986), resulting in a value for $\boldsymbol{Z}=1,96$, assuming that the ratio is not known and therefore $\boldsymbol{p}=\boldsymbol{q}=0,5$, as it provides the largest likely sample size and taking $\boldsymbol{d}$ (sample error) as 0,10 , assuming $+/-10 \%$ intervals of variation on the average of the TFI points provide a clear definition of the adopted tendency, the minimum sample size would be 35 companies. The result was a number of 73 completed questionnaires comprising 38 companies. Since the total population of services firms was not known, a sample of 43 companies was used in order to be able to perform the statistical test required in this study.

Secondly, care was taken regarding the statistical analyses of reliability and validity. Relevant literature suggests that Factor Analyses - as those used here - should have a sample size that is relatively large in comparison to the number of variables involved. There is a series of suggestions for the choice of such a sample size. Generally, the options are based on the personal experience of the authors who, in some cases, suggest that the sample size should range from 5 to 20 times the size of the variables with no less than fifty observations, and at least 100 observations being the number of choice (Artes, 1998; Kline, 1994; Menezes, 1998). Thus, our sample meets the conditions required and the expected objectives. The information on the demographic data of the sample is given in Table 2. 
Table 2: Demographic Data of the Sample

\begin{tabular}{|c|c|c|c|c|c|c|c|c|}
\hline \multirow{3}{*}{ Criteria } & \multicolumn{8}{|c|}{ Companies } \\
\hline & \multicolumn{2}{|c|}{ Technology-based } & \multicolumn{3}{|c|}{ Traditional } & \multicolumn{3}{|c|}{ Total } \\
\hline & $\mathrm{N}$ & $(\%)$ & $\mathrm{N}$ & $(\%)$ & & $\mathrm{N}$ & $(\%$ & \\
\hline$<20$ & 4 & 5.5 & 0 & 0 , & $\overline{0}$ & 4 & & 3.5 \\
\hline$[20,25)$ & 20 & 27.4 & 3 & 7. & 1 & 23 & & 20.0 \\
\hline$[25,30)$ & 25 & 34.2 & 6 & 14. & & 31 & & 27.0 \\
\hline$[30,35)$ & 3 & 4.1 & 4 & 9. & 5 & 7 & & 6.1 \\
\hline$[35,40)$ & 8 & 11.0 & 8 & 19. & & 16 & & 13.9 \\
\hline$[40,45)$ & 2 & 2.7 & 12 & 28. & & 14 & & 12.2 \\
\hline$\geq 45$ & 5 & 6.8 & 9 & 21. & & 14 & & 12.2 \\
\hline $\mathrm{N} / \mathrm{I}^{*}$ & 6 & 8.2 & 0 & 0 . & 0 & 6 & & 5.2 \\
\hline Mean & \multicolumn{2}{|c|}{27.9} & \multicolumn{3}{|c|}{38.3} & \multicolumn{3}{|c|}{31.9} \\
\hline Respondents & 73 & 63.5 & 42 & 36. & & 115 & & 100.0 \\
\hline \multicolumn{9}{|l|}{ Gender } \\
\hline Male & 56 & 76.7 & 32 & 76. & & 88 & & 76.5 \\
\hline Female & 17 & 23.3 & 10 & 23. & & 27 & & 23.5 \\
\hline \multicolumn{9}{|l|}{ Type of team } \\
\hline Team from hell & 0 & 0.0 & 0 & 0 . & 0 & 0 & & 0.0 \\
\hline Standard team & 3 & 4.1 & 6 & 14. & & 9 & & 7.8 \\
\hline Dream team & 70 & 95.9 & 36 & 85. & & 106 & & 92.2 \\
\hline Incubator & Inc-01 & Inc-02 & Inc-03 & Inc-04 & Inc-05 & Inc-06 & Inc-07 & Inc-08 \\
\hline Number of companies & 9 & 6 & 3 & 2 & 9 & 3 & 4 & 2 \\
\hline$(\%)$ & 12 & 8 & 4 & 3 & 12 & 4 & 5 & 3 \\
\hline Number of respondents & 21 & 13 & 3 & 3 & 16 & 9 & 5 & 3 \\
\hline$(\%)$ & 29 & 18 & 4 & 4 & 22 & 12 & 7 & 4 \\
\hline Location & Maringá & $\begin{array}{c}\text { Pato } \\
\text { Branco }\end{array}$ & Cascavel & Curitiba & Curitiba & Londrina & $\begin{array}{c}\text { São } \\
\text { Mateus } \\
\text { do Sul }\end{array}$ & $\begin{array}{l}\text { Foz de } \\
\text { Iguaçu }\end{array}$ \\
\hline
\end{tabular}

Out of 115 questionnaires, $50 \%$ of the respondents are under 30 years of age, the youngest being 16 and the oldest, 60 years old, with a mean age of 32 years. A significant difference was found between the age of the owner-managers of technology-based companies and the owner-managers of traditional firms of services, with the former being an average of 10 years younger than the latter. There was a disproportion in the number of respondents from the groups under analysis, with $64 \%$ from the technology-based companies and 36\% from the traditional firms. This research considered the micro and small-sized companies that had from 10 to 50 employees. In terms of gender, $76 \%$ of the subjects were male and $24 \%$ female.

From the micro and small-sized resident companies, 73 questionnaires were completed by respondents from 38 companies located in eight incubators from Paraná. Most companies (75\%) are from the areas of technology, agribusiness, production of commercial and entertainment software, industrial automation and Internet solution. In general, the incubators have existed for no longer than three years. Table 2 presents the information regarding the number of companies investigated in each incubator and the number of respondents from each company and the location of the incubators. 


\section{RESULTS}

Below we discuss the results of reliability and validity of the TFI in order to support our analyses. This section consists of three sub-sections. The first sub-section contains the analysis of validity, the second analyzes reliability, and the third presents additional analyses with the purpose of showing the vigor of this research instrument even if used in different cultures.

\section{Construction Validity}

Two of the main forms of assessing validity are: internal and external validity. We have addressed only the internal validity of the instruments in this article because of the existence of other papers reporting on the external validity of the TFI (Inácio \& Gimenez, 2002). In regard to the internal validity, two procedures may be adopted: content validity and construction validity. The former involves a conceptual component and the latter an operational component. The former also refers to the evaluation, by the researcher, as to whether the instrument reflects the phenomenon to be measured. This is a subjective judgment whose evaluation cannot be made by means of statistical methods but with an examination of the literature and of the theory or theories underlying the phenomenon under study. It is therefore a procedure dependent on the historical context (Menezes, 1998).

The second procedure, in turn, involves the systematic evaluation of the instrument, with the analysis of how the items correlate to their respective factors. In this section, we address the construction validity by means of a factor analysis ${ }^{(1)}$. This is a multivariate analysis that is applied in the identification of factors within a set of undertaken measures (Pereira, 1999). According to the theoretical proposition of the TFI, it consists of seven factors of creative teams. The literature provides several criteria that help to identify the number of factors that whenever used in the same set of data leads to different results invariably (Artes, 1998). Among these criteria is that of Kaiser, the criterion of the percentage of explained variance, the scree test criterion and the inferential methods.

Rickards et al. (2001) used in their research the Kaiser method and the result evidenced that the pattern that mostly represented the structure of correlation of items and factors was obtained with the use of seven factors. Applying this same criterion of extraction of factors - the Kaiser method - our research produced a different amount of factors - in our case, five - smaller than that proposed in the theory. This may be verified by the Eigenvalues in Table 3. Only the first five factors have values higher than 1, as claimed by this criterion. Nevertheless, we decided to present and evaluate the factor analysis with the extraction of seven factors, as the objective was to verify the adequacy in relation to the theoretical proposition.

The factor analysis evidenced that all the questions had factor loadings above 0.30 , and the majority was close to 0.70 , representing a good internal validity of the instrument. Despite the fact that six items did not have their highest factor loadings in their respective factors, all of them presented significant factor loadings $(\geq 0.30)$. Factors PE, RE and CL require further analysis as each one of their items loaded in different factors and did not indicate a propensity. Nevertheless, the seven factors have multiple questions. The factor analysis of the TFI also presented a good balance between the quantity of factors and the percentage of their explanation (percentage of accumulated variance explaining $71 \%$ of the total). The literature evidences an explanation close to $70 \%$. 
Table 3: Factor Analysis of the TFI

\begin{tabular}{|c|c|c|c|c|c|c|c|}
\hline \multirow{2}{*}{$\frac{\text { Items }}{\text { Shared vision }}$} & \multicolumn{7}{|c|}{ Factor 1Factor 2Factor 3Factor 4Factor 5Factor 6Factor 7} \\
\hline & & & & & & & \\
\hline VC6 & 0.78 & 0.17 & 0.10 & 0.03 & 0.33 & -0.04 & -0.02 \\
\hline VC7 & 0.71 & 0.21 & 0.00 & -0.02 & 0.20 & 0.26 & 0.32 \\
\hline VC13 & 0.71 & 0.01 & 0.08 & 0.26 & -0.02 & 0.21 & 0.21 \\
\hline \multicolumn{8}{|l|}{ Platform of understanding } \\
\hline PE19 & 0.55 & 0.07 & 0.31 & 0.10 & 0.05 & 0.08 & 0.52 \\
\hline PE27 & 0.24 & 0.15 & 0.09 & 0.17 & 0.10 & 0.11 & 0.74 \\
\hline PE35 & 0.16 & 0.80 & 0.14 & 0.07 & 0.14 & 0.13 & 0.23 \\
\hline \multicolumn{8}{|l|}{ Chain activation } \\
\hline AR17 & 0.12 & 0.10 & 0.87 & 0.14 & 0.10 & -0.05 & 0.10 \\
\hline AR21 & 0.29 & 0.21 & 0.41 & 0.13 & -0.03 & 0.63 & -0.21 \\
\hline AR23 & 0.01 & 0.02 & 0.81 & 0.06 & 0.18 & 0.29 & 0.12 \\
\hline \multicolumn{8}{|l|}{ Resilience } \\
\hline RE16 & 0.10 & 0.30 & 0.19 & 0.80 & 0.00 & 0.03 & 0.14 \\
\hline RE20 & 0.38 & 0.20 & 0.36 & 0.30 & 0.14 & 0.04 & 0.44 \\
\hline RE34 & 0.15 & 0.67 & -0.05 & 0.50 & 0.06 & 0.11 & -0.13 \\
\hline \multicolumn{8}{|l|}{ Own ideas } \\
\hline IP2 & 0.00 & 0.34 & 0.12 & 0.08 & 0.57 & 0.32 & 0.21 \\
\hline IP4 & 0.28 & 0.28 & 0.12 & 0.04 & 0.78 & -0.02 & -0.01 \\
\hline IP9 & 0.15 & -0.16 & 0.20 & 0.14 & 0.70 & 0.26 & 0.25 \\
\hline \multicolumn{8}{|l|}{ Learning from experience } \\
\hline AE14 & 0.28 & 0.09 & 0.03 & 0.28 & 0.23 & 0.62 & 0.16 \\
\hline AE15 & 0.05 & 0.22 & 0.03 & 0.02 & 0.18 & 0.64 & 0.46 \\
\hline AE33 & -0.01 & 0.42 & 0.23 & 0.33 & 0.18 & 0.50 & 0.15 \\
\hline \multicolumn{8}{|l|}{ Climate } \\
\hline CL26 & 0.18 & 0.15 & 0.26 & 0.32 & 0.34 & 0.10 & 0.55 \\
\hline CL32 & 0.06 & -0.07 & 0.11 & 0.68 & 0.24 & 0.35 & 0.23 \\
\hline CL36 & 0.27 & 0.55 & 0.12 & 0.11 & 0.13 & 0.26 & 0.37 \\
\hline Eigenvalue & 7.75 & 1.58 & 1.47 & 1.21 & 1.11 & 0.97 & 0.88 \\
\hline $\begin{array}{l}\text { Accumulated percentage of } \\
\text { Variance }\end{array}$ & 36.90 & 44.40 & 51.42 & 57.18 & 62.46 & 67.09 & 71.26 \\
\hline
\end{tabular}

\section{Reliability}

The internal consistency indicates the extension each item of the TFI inter-relates to one another (Hayes, 1994). The greater the inter-relationship between the item, the greater is the internal consistency. The underlying concept to internal consistency is that if an instrument designed to measure a given characteristic, e.g., the shared vision in the TFI, has more than one item for that same characteristic, then these items are expected to relate to one another (Hayes, 1994). This means that the individuals that respond in a certain way to an item (in an affirmative way, in this case) most probably will respond in the same way to another item with the same characteristic. As an example, we may quote TFI affirmative statement PE19: Members of the same team have a good understanding of one another's beliefs and presuppositions and affirmative statement PE35: Members of the team have a good understanding of one another's personal needs.

There are several types of statistics used to estimate the degree of internal consistency, and the most common tests are the Split-half and Cronbach's Alpha ${ }^{(2)}$ (Cooper \& Schindler, 2002; Hayes, 1994). The Split-half can be used whenever the instrument has several questions or similar affirmative 
statements the individual may respond to (Cooper \& Schindler, 2002). Normally, the results are separated into odd and even items. If the result of the correlation between the halves is high, the instrument is said to be of high reliability in terms of internal consistency. According to Bruning and Kintz (Carland, J. A. Carland, \& Hoy, 1992) the correlation indices (split-half, Guttman, Cronbach's Alpha) produce valid results if the statistical correlation is equal to or above 0.70 . Table 4 presents the results from the TFI Split-half test.

Table 4: Analysis of Reliability: Internal Consistency - TFI Split-half

\begin{tabular}{cccccl}
\hline \multicolumn{6}{c}{$\begin{array}{c}\text { Correlation between the first and second halves }=0.84 \\
\text { Split-half reliability }=0.91 \text { Guttman split-half reliability }=0.91\end{array}$} \\
\hline Halves & $\begin{array}{c}\text { No. } \\
\text { items }\end{array}$ & Mean & SD $\begin{array}{c}\text { Cronbach's } \\
\text { Alpha }\end{array}$ & \multicolumn{1}{c}{ Questions } \\
\hline 1 st & 11 & 3.91 & 0.27 & 0.84 & $\begin{array}{l}\text { IP2, VC6, IP9, AE14, RE16, AR17, PE19, AR23, PE 27, CL32 } \\
\text { e RE34 } \\
\text { IP4, VC7, VC13, AE15, RE20, AR21, CL26, AE33, PE35 e } \\
\text { CL36. }\end{array}$ \\
\hline
\end{tabular}

As presented in Table 4, both indices of correlation (split-half and Guttman) produced values above 0.70 . The correlation between the two halves was 0.82 ; however, this value may have been influenced by the uneven number of questions between the two halves as the TFI has a total of 21 affirmative statements. Cooper and Schindler (2002) also claimed that a problem in this test is that the way both halves are divided may influence the correlation. A reason for this may be that as the questions were separated into odd and even items, all the affirmative sentences concerning one single characteristic may have been laid on one single side, for example, and therefore, the other half of the sentences would hardly find a strong correlation. In general, the data show a statistically significant index of correlation, indicating that the instrument is consistent and has a related structure of items.

As mentioned previously, this test is greatly affected by the way the two halves were divided. Thus, the most commonly used index is that of Cronbach's Alpha, as it assures a reliable estimate and does not require the division of the tested items (Cooper \& Schindler, 2002). The index varies from 0 to 1. A reliability of 0 would suggest that the observed score does not relate to the true designed score, and a 1 reliability would mean that the score is perfectly related to the true designed score (Hayes, 1994). According to some authors, values equal to or above 0.80 are acceptable in terms of reliability (Hayes, 1994), whereas other authors would accept values equal to or above 0.70 (Carland, Carland, \& Hoy, 1992). However, as pointed out by Pereira $(1999$, p. 87) "the researcher will find it difficult to say whether the achieved level is satisfactory as there is no ideal cutting point for the conception of an indicator whatsoever".

As shown in Table 5, both the mean and the variance did not indicate any item that could have contributed to or adversely affected the TFI. The item and total correlation indicated a strong interrelationship of items. All the values ranged from 0.24 to 0.25 . The Cronbach's alpha for each item virtually had no alterations in relation to the general alpha 0.90 , meaning an excellent internal consistency. In fact, despite the fact that the TFI is at the very initial stage of its process of validation and that it is not very often used in the international context, it obtained very good indices of validation and reliability in comparison to those in the original version as researched by Rickards et al. (2001). In that study, the Cronbach's alpha was 0.94 . 
Table 5: Analysis of Reliability: Internal Consistency -Cronbach’s Alpha of the TFI

\begin{tabular}{|c|c|c|c|c|c|c|c|c|c|}
\hline Cronbacl & h's alph & $\begin{array}{r}\text { Scal } \\
\text { a: } 0.91 \mathrm{St}\end{array}$ & $\begin{array}{l}\text { e summar } \\
\text { andardize }\end{array}$ & $\begin{array}{r}\text { lean }=3 . \\
\text { pha: } 0.9 \\
\text { total: }\end{array}$ & $\begin{array}{l}\text { o S.D. }=0 \\
\text { / Correcte } \\
0.34\end{array}$ & $\begin{array}{l}.52 \text { Valic } \\
\text { ed correl }\end{array}$ & $\begin{array}{l}\text { d n:111 } \\
\text { lation me }\end{array}$ & an betw & tem and \\
\hline Questions & $\begin{array}{l}\text { Mean if } \\
\text { item } \\
\text { remove } \\
\text { d }\end{array}$ & $\begin{array}{l}\text { Variance } \\
\text { if item } \\
\text { removed }\end{array}$ & $\begin{array}{l}\text { Corrected } \\
\text { correlatio } \\
\mathrm{n} \text { between } \\
\text { item and } \\
\text { total }\end{array}$ & $\begin{array}{l}\text { Alpha if } \\
\text { item } \\
\text { removed }\end{array}$ & Questions & $\begin{array}{l}\text { Mean if } \\
\text { item } \\
\text { remove } \\
d\end{array}$ & $\begin{array}{l}\text { Variance } \\
\text { if item } \\
\text { removed }\end{array}$ & $\begin{array}{c}\text { Corrected } \\
\text { correlatio } \\
\mathrm{n} \text { between } \\
\text { item and } \\
\text { total }\end{array}$ & $\begin{array}{l}\text { Alpha if } \\
\text { item } \\
\text { removed }\end{array}$ \\
\hline IP2 & 3.69 & 0.25 & 0.56 & 0.90 & RE20 & 3.70 & 0.24 & 0.61 & 0.90 \\
\hline IP4 & 3.70 & 0.25 & 0.50 & 0.90 & AR21 & 3.71 & 0.25 & 0.48 & 0.91 \\
\hline VC6 & 3.71 & 0.25 & 0.47 & 0.91 & AR23 & 3.70 & 0.25 & 0.47 & 0.91 \\
\hline VC7 & 3.71 & 0.24 & 0.62 & 0.90 & CL26 & 3.69 & 0.24 & 0.64 & 0.90 \\
\hline IP9 & 3.70 & 0.25 & 0.52 & 0.90 & PE27 & 3.70 & 0.25 & 0.55 & 0.90 \\
\hline VC13 & 3.71 & 0.25 & 0.52 & 0.90 & CL32 & 3.70 & 0.25 & 0.45 & 0.91 \\
\hline AE14 & 3.71 & 0.25 & 0.59 & 0.90 & AE33 & 3.70 & 0.25 & 0.58 & 0.90 \\
\hline AE15 & 3.70 & 0.25 & 0.55 & 0.90 & RE34 & 3.72 & 0.25 & 0.44 & 0.91 \\
\hline RE16 & 3.70 & 0.25 & 0.52 & 0.90 & PE35 & 3.72 & 0.25 & 0.58 & 0.90 \\
\hline AR17 & 3.70 & 0.25 & 0.43 & 0.91 & CL36 & 3.71 & 0.24 & 0.65 & 0.90 \\
\hline PE19 & 3.72 & 0.25 & 0.59 & 0.90 & & & & & \\
\hline
\end{tabular}

\section{Additional Analyses}

Another way of having further analysis of reliability and validity of the TFI Portuguese version is the verification of a likely association between the scores of the TFI and the variables of gender and group. The researchers agree that there are psychological and social differences between males and females concerning their way of acting and thinking during innovative and entrepreneurial processes, but not in terms of their capacity and potential to start a business (Carland \& Carland, 1991; Fleenor \& Taylor, 1994; Gartner \& Shane, 1995). Therefore, it is expected that there will be a non significant difference between the averages of male and female respondents. If the results are those expected, this may mean that the Portuguese version of the TFI is a good instrument for telling the difference between the potential entrepreneur and an individual. Table 6 indicates that the nullity hypothesis was accepted, and the conclusion that there is no statistically significant difference between the mean score of the TFI between the males and females, at $5 \%$ level

Table 6: Average of TFI per Gender

\begin{tabular}{l|c|c|c}
\hline \multicolumn{1}{c}{ Gender } & TFI average & S.D. & N \\
\hline Female & 3.95 & 0.54 & 27 \\
\hline Male & 3.88 & 0.52 & 88 \\
\hline$p=0.5368$ (not significant at $5 \%$ level)
\end{tabular}

On the other hand, the TFI could serve to discriminate between respondents from technology-based companies and those from traditional firms of services. The hypothesis is that owner-managers of technology-based companies will have a higher score than those of traditional services. For this, the ANOVA one-way test was used in order to test the nullity hypothesis that the averages of the groups of analysis were not different. As shown in Table 7, the nullity hypothesis was rejected, and it is concluded that there is a statistically significant difference between the TFI average score of technology-based companies and traditional firms at $5 \%$. 
Table 7: Anova one-way summary

\begin{tabular}{l|r|c|c|c|c}
\hline Source of variation & d.f. & SS & MS & Fvalue & PValue \\
\hline Model TFI & 1 & 5.077410 & 5.077410 & 22.14469 & 0.00007 \\
\hline Residual Error & 113 & 25.90903 & 0.229283 & & \\
\hline Total & 114 & 30.98644 & & & \\
\hline $\begin{array}{l}\text { Factor: group of analysis } \\
\text { Dependent: TFI score }\end{array}$ \\
\hline
\end{tabular}

Summary

\begin{tabular}{c|c|r|r|c}
\hline Group & Code & \multicolumn{1}{c|}{ Count } & Mean & \multicolumn{1}{c}{ S.D. } \\
\hline Technology-based company & TEC & 73 & 4.06 & 0.46 \\
\hline Traditional firms of services & TRA & 42 & 3.62 & 0.51 \\
\hline
\end{tabular}

A word of caution in the interpretation of these results must be given. Over $70 \%$ of the respondents in the companies have a higher degree of education and had previous knowledge of entrepreneurial theories and models. This previous experience certainly took place in a favorable environment as many Brazilian undergraduate courses have emphasized the need to promote entrepreneurial and innovative behavior. Furthermore, the current social climate in Brazil for entrepreneurship has been stimulated by deliberate government policies. This, probably, influences the potential toward an entrepreneurial attitude of the respondents (Fiet, 2001a, 2001b).

\section{FinAL CONSIDERATIONS}

Our intention has been to discuss the reliability and validity of the Portuguese version for the Team Factors Inventory - TFI. As a preliminary discussion for further studies, this article evidenced that the translated version was useful for the measurement of the potential for Creative Leadership and, in general, it achieved good levels of validity and reliability. This is an important conclusion as it allows the academic community to have at their disposal an instrument to measure leadership and entrepreneur behavior in the context of Brazilian companies.

A potential benefit in having a well designed and validated instrument to measure entrepreneurial behavior in Brazil is that it can contribute to more efficient and effective government policies toward entrepreneurship. This instrument may be used, for example, as an additional tool for public and private agents such as technology-based incubators to analyze potential entrepreneurs and their business plans. The incubators have recently reported in research works that the most important element used in the selection of candidates to be incubated has been their own entrepreneurial profile (ANPROTEC, 2001).

Furthermore, the TFI has been proven helpful in the self-evaluation process of the team. With results from each of the seven factors of creative teams and with additional training for the team to understand the concepts and presuppositions, the instrument becomes a tool for the management of the capacity for Creative Leadership and, therefore, the capacity to innovate and enterprise.

Further studies will have, at first, to turn to the analysis of the relation between the items of the instrument and its theoretical model. This is necessary because, as mentioned above, six out of the twenty-one items did not relate to their due factors as they should. Secondly, some items will have to be revised in face of a possible Brazilian culture preference, although the results seem to indicate universal validity for the instrument and original model. The high rates of internal consistency, as presented, indicate that there is no difficulty to understand the ideas presented in the Portuguese 
version. Finally, for further studies, it would be advisable to verify how the Portuguese version of the TFI would apply to a larger and more diversified population.

\title{
NOTES
}

\begin{abstract}
${ }^{1}$ For those readers not familiar with some important concepts, here are their definitions: factor loading: measure of correlation between the derived function and the original measures. It may be interpreted in the same way as the correlation coefficient of Pearson; Eigenvalue: measure of how much of the total variance of achieved measure can be explained by the factor. The Eigenvalue evaluates the contribution given by the factor to the model constructed by the AF; factorial matrix: the matrix of correlation between the variables and the identified factors (Pereira, 1999, p. 123-4).

${ }^{2}$ For those readers not familiar with some important concepts, here are their definitions: Mean if item is removed: the arithmetic index mean, that is, the TFI without that item. The lower the value of the mean of the item, the greater the contribution of this item to the index; Variance if item is removed: variance between the means found for the item. The lower the variance of the item, the greater the contribution for the variance, which is undesirable; Corrected correlation between item and total: correlation coefficient of Person (r) between the specific item and the total index, depurated from its own contribution; Alpha if item is removed: evidences the impact of the removal of each item considered upon the performance index. The inexistence of big differences between the items suggests a good internal consistency for the index, which could be kept the way it is and without the exclusion of any item (Pereira, 1999, p. 87-8).
\end{abstract}

\section{REFERENCES}

Alencar, E. M. L. S. D. (1995, novembro/dezembro). Desenvolvendo a criatividade nas organizações: o desafio da inovação. Revista de Administração de Empresas, 35(6), 6-11.

Alencar, E. M. L. S. D. (1998, abril/junho). Promovendo um ambiente favorável à criatividade nas organizações Revista de Administração de Empresas, 38(2), 18-25.

Amabile, T. (1998, September/October). How to kill creativity. Harvard Business Review, 76(5), 7787.

Associação Nacional de Entidades Promotoras de Empreendimentos de Tecnologia Avançadas ANPROTEC (2001). Panorama 2000. Recuperado em 8 abril, 2001, de http://www.anprotec.org.br.

Artes, R. (1998, setembro/outubro). Aspectos estatísticos da análise fatorial de escalas de avaliação. Revista de Psiquiatria Clínica, 25(5), 223-228.

Bennis, W. G., \& Biederman, P. W. (1997). Organizing genius: the secret of creative collaboration. Reading: Addison-Wesley Publishing Company.

Brockhaus, R. H. (1982). The psychology of the entrepreneur. In C. A. S. Kent, L. Donald, \& K. H. Vesper (Eds.). Encyclopedia of entrepreneurship. Englewood Cliffs, NJ.: Prentice-Hall.

Brush, C. G., Greene, P. G., \& Hart, M. M. (2002, janeiro/março). Empeendedorismo e construção da base de recursos. Revista de Administração de Empresas, 42(1), 20-35.

Bruyat, C., \& Julien, P. A. (2001, March). Defining the field of research in entrepreneurship. Journal of Business Venturing, 16(2), 165-180.

Burns, J. M. (1979). Leadership. New York: Harper \& Row.

Carland, J. W., Carland, J. A. C., Hoy, F. S. (1992). An entrepreneurship Index: an empirical validation. Proceedings of the Frontiers of Entrepreneurship Research, France. Retrieved November 10, 2001, from http://www.babson.edu/entrep/fer/front_92.html. 
Carland, J. W., Hoy, F., Boulton, W. R., \& Carland, J. A. C. (1984, April). Differentiating entrepreneurs from small business owners: a conceptualization. The Academy of Management Review, 9(2), 354-360.

Carland, J. W., \& Carland, J. A. (1991, April/June). An empirical investigation into the distinctions between male and female entrepreneurs and managers. International Small Business Journal, 9(3), 62-72.

Cooper, D. R., \& Schindler, P. (2002). Business research methods (8th ed.). New York: McGrawHill/Irwin.

Craig, C. S., \& Douglas, S. P. (2000) International marketing research (3rd ed.). Englewood Cliffs, New Jersey: Prentice-Hall.

Fiet, J. O. (2001a, March). The pedagogical side of entrepreneurship theory. Journal of Business Venturing, 16(2), 101-117.

Fiet, J. O. (2001b, March). The theoretical side of teaching entrepreneurship. Journal of Business Venturing, 16(1), 1-24.

Filion, L. J. (1999a, outubro/novembro). Diferenças entre sistemas gerenciais de empreendedores e operadores de pequenos negócios. Revista de Administração de Empresas, 39(4), 6-20.

Filion, L. J. (1999b, abril/junho). Empreendedorismo: empreendedores e proprietários-gerentes de pequenos negócios. Revista de Administração, 34(2), 5-28.

Fleenor, J. W., \& Taylor, S. (1994, Summer). Construct validity of three self-report measures of creativity. Educational and Psychological Measurement, 54(2), 464-470.

Gartner, W. B., \& Shane, S. (1995, July). Measuring entrepreneurship over time. Journal of Business Venturing, 10(4), 283-301.

Hayes, B. E. (1994, February). How to Measure empowerment. Quality Progress, 27(2), 41-48.

Hornaday, J. A. (1982). Research about living entrepreneurs. In C. A. S. Kent, L. Donald, \& K. H. Vesper (Eds.). Encyclopedia of entrepreneurship. Englewood Cliffs, NJ.: Prentice-Hall.

Huefner, J. C., Hunt, H. K., \& Robinson, P. B. (1996, Autumn). A comparison of four scales predicting entrepreneurship. Academy of Entrepreneurship Journal, 1(2), 56-80.

Inácio, E., Jr. (2002) Empreendedorismo e liderança criativa: um estudo com os proprietáriosgerentes de empresa incubadas no estado do Paraná. Unpublished Master's degree dissertation, Universidade Estadual de Maringá, Maringá, PR., Brasil.

Inácio, E., Jr. \& Gimenez, F. A. P. (2002). Investigando o potencial empreendedor e de liderança criativa. Anais do Encontro Nacional dos Programas de Pós-Graduação em Administração, Salvador, BA, 26.

Inácio, E., Jr., Gimenez, F. A. P., \& Caetano, J. M. V. (2002). Creative leadership and entrepreneurs: an empirical investigation on Brazilian owner-manager of enterprises in business incubators. Proceedings of the British Academy of Management Annual Conference, London, Inglaterra.

Kets de Vries, M. F. R. (1985, November/December). The dark side of entrepreneurship. Harvard Business Review, 63(6), 160-167.

Kline, P. (1994). An easy guide to factor analysis. London: Routledge.

Knight, G. A. (1997, May). Cross-cultural reliability and validity of a scale to measure firm entrepreneurial orientation. Journal of Business Venturing, 12(3), 213-225.

Lipman-Blumen, J. (2000). Connective leadership: managing in a changing world. Oxford: Oxford University Press. 
Menezes, P. R. (1998, setembro/outubro). Validade e confiabilidade das escalas de avaliação em psiquiatria. Revista de Psiquiatria Clínica, 25(5), 214-216.

Nonaka, I., \& Takeuchi, H. (1997). Criação de conhecimento na empresa: como as empresas japonesas geram a dinâmica da inovação. Rio de Janeiro: Campus.

Pereira, J. C. R. (1999). Análise de dados qualitativos: estratégias metodológicas para as ciências da saúde, humanas e sociais. (2nd ed.). São Paulo: Ed. UNESP.

Rickards, T.(1999). Creativity and the management of change. Oxford: Blackwell.

Rickards, T., \& Moger, S. (1999). Handbook for creative team leaders. UK: Gower.

Rickards, T., \& Moger, S. (2000, December). Creative leadership processes in project team development: an alternative to Tuckman's stage model. British Journal of Management, 11(4), 273-283.

Rickards, T., Chen M., \& Moger S. (2001, September) Development of a self-report instrument for exploring team factor, leadership and performance relationships. British Journal of Management, $12(3), 243-250$

Silver, M. (2000). Estatística para administração. São Paulo: Atlas.

Singleton, R. A., Jr., \& Straits, B. C. (1993). Approaches to social research (3th ed.). Oxford: Oxford University Press.

Steverson, W. J. (1986). Estatística aplicada à administração. São Paulo: Harbra.

Stewart W. H., Jr., Watson, W. E., Carland, J. A. C., \& Carland, J. W. (1999, March). A proclivity for entrepreneurship: a comparison of entrepreneurs, small business owners, and corporate managers. Journal of Business Venturing, 14(2), 189-214.

Tuckman, B. W. (1965, June). Developmental sequences in small groups. Psychological Bulletin, 63(6), 384-399.

Vesper, K. H., \& Gartner, W. B (1997, September). Measuring progress in entrepreneurship education. Journal of Business Venturing, 12(5), 403-421. 


\section{ANEX A \\ TFI - PORTUGUESE Version}

1) Com base em sua equipe de trabalho, responda cada item abaixo marcando em uma escala de 5 a 1 ( $5=$ concorda fortemente; $4=$ concorda; $3=$ neutro; $2=$ discorda; $1=$ discorda fortemente).

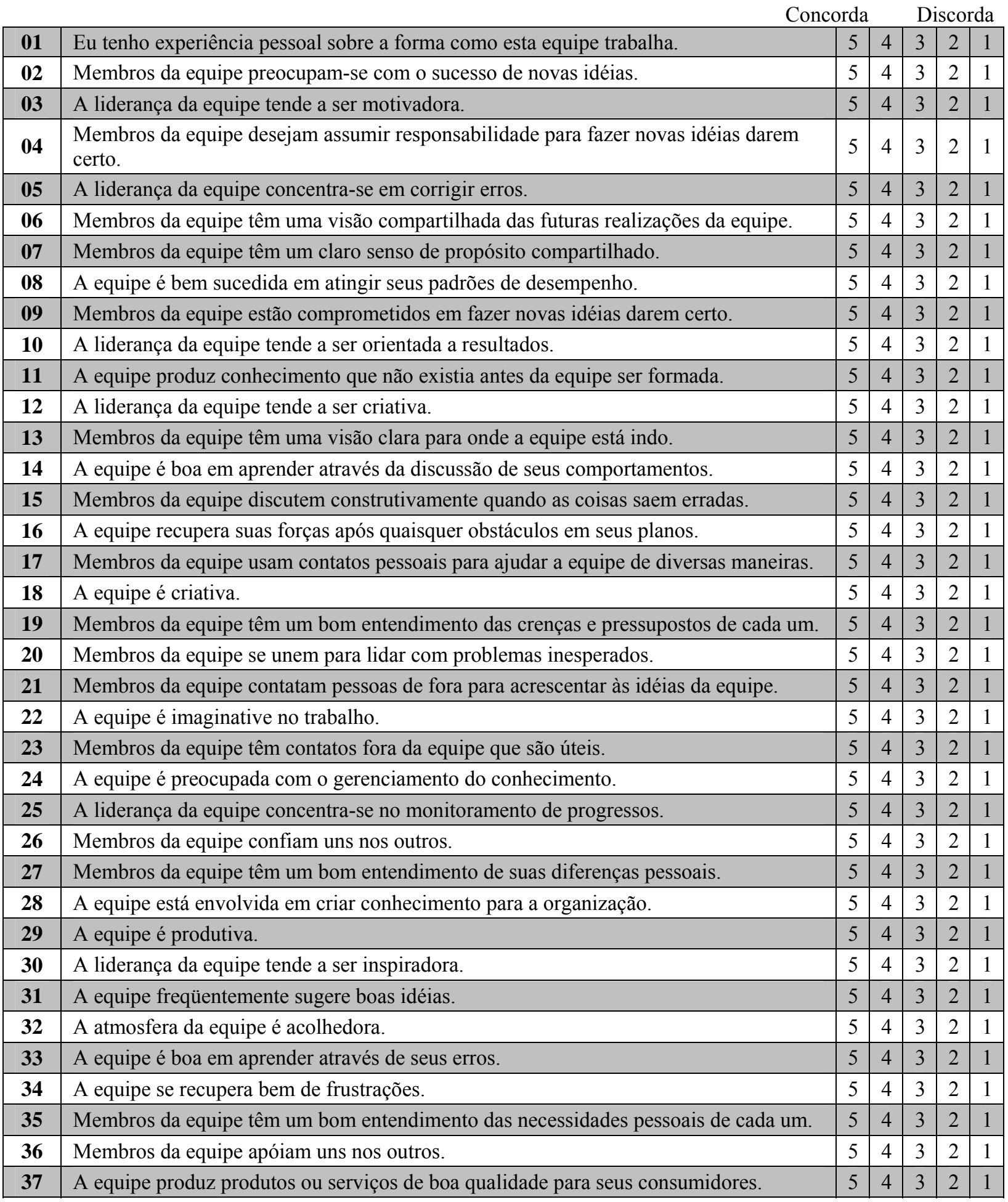

